\title{
Epidemiology of osteoporosis in Latin America 2008
}

\author{
Gregorio Riera-Espinoza, MC(1)
}

\section{Riera-Espinoza G. \\ Epidemiology of osteoporosis in Latin America 2008. Salud Publica Mex 2009;5 I suppl I:S52-S55.}

\begin{abstract}
Osteoporosis is a growing disease in Latin America, rates of fractures actually in LA are quite similar to the ones in Southern Europe and slightly lower than USA and Northern Europe. According to the population projection of the WHO subjects over 65 of age will increase significantly in the next 50 years in LA and the number of hip fractures in this area will equal the numbers in Europe and USA. Unfortunately, in LA there are not adequate resources in terms of medical facilities for osteoporosis diagnosis, treatment or rehabilitation. Moreover, there are no policies of reimbursement for osteoporosis densitometry, bone markers measurements or medications in many countries or it is very limited in the ones who have started some kind of specific program for this matters. Thus, we have to face this public health problem by increasing the awareness of the disease in the general population, specific risk groups, schools, journalists or politicians. Improve medical education at different levels: Medical students, General Practitioners, Specialists, Nurses, and Social Workers. And, we have to develop enough influence to Public and Private Health Systems in order to make them to develop specific osteoporosis programs to cover a wide range of the population in LA, who actually is absolutely abandon of this kind of support.
\end{abstract}

Key words: osteoporosis; Latin America; public health

\section{Riera-Espinoza G.}

Epidemiología de la osteoporosis en Latino América. Salud Publica Mex 2009;5I supl I:S52-S55.

\section{Resumen}

La osteoporosis es una enfermedad que se vuelve cada vez más frecuente en América Latina. Su prevalencia es muy parecida a la encontrada en Europa del Sur y ligeramente más baja que en Europa del Norte y en la población blanca de los EUA. De acuerdo a las proyecciones de población de la $\mathrm{OMS}$, el número de fracturas que se registrarán en la región de Latino América en los próximos 50 años casi igualará los números encontrados en EUA y Europa. Desafortunadamente en Latino América no hay recursos médicos suficientes para el diagnóstico, tratamiento y rehabilitación de la osteoporosis. En muchos países no existen leyes (o son muy limitadas) que garanticen el pago de los estudios de densitometría ósea, las medidas de prevención o los medicamentos para tratarla. Actualmente, es posible enfrentar este problema de salud pública generando conciencia de la enfermedad en el público general, en los grupos de riesgo y en las escuelas, con el apoyo de periodistas y sensibilizando a los políticos. También se debe mejorar la educación médica a nivel de las escuelas de medicina, entre los médicos generales, los especialistas, las enfermeras y los trabajadores sociales; se debe lograr suficiente influencia en el sistema de salud pública y privada para hacer que se desarrollen programas específicos contra la osteoporosis, que cubran al amplio rango de población Latinoamericana que actualmente no tiene ninguna clase de apoyo.

Palabras clave: osteoporosis; América Latina; salud pública 


\section{Population}

The population of LA and the Caribbean was 524 million in year 2000. 5.57\% were 65 years and older. Total population will grow $16 \%$ by 2010 but people over 50 will grow 28\%. In Argentina and Uruguay this group was over 10\%, 9.6\% in Cuba and 7.2\% in Chile. Inhabitants aged 50 and over represent $14.62 \%$ of the total population ranging from 9 to $26.9 \%$ among different countries. In terms of ethnic composition, the Mestizo group predominates in most Latin American countries. Information regarding fracture incidence in different ethnic groups is lacking with the exception of a few studies in North America.

Life expectancy in the region reached 70 years and mean Gross National Income ranges from 410 to 7550 USD with a mean of 2776 USD. Access to medical care is variable from country to country though most of them have social security systems, but a high proportion of the population use a free-for-service model where policies of reimbursement for osteoporosis diagnosis and treatment is uncommon. ${ }^{1-4}$

\section{Prevalence of low bone mass}

Peak bone mass and bone loss with age is similar in Latin American countries in comparison to the US, the prevalence of vertebral osteopenia in women 50 years and older range from 45.5 to $49.6 \%$ and vertebral osteoporosis from 12.1 to $17.6 \%$. In femoral neck osteopenia is present from 46 to $57 \%$ and osteoporosis from 7.9 to $22 \%$. ${ }^{5-11}$ In Brazil, 10 million people, approximately one person in every 17 , has osteoporosis. ${ }^{12}$

In Chile, in 1985, a large clinical trial of women older than 50 indicated that $46 \%$ had osteopenia and $22 \%$ had

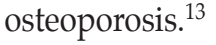

In Mexico, in 1998, one out of every four people has osteopenia or osteoporosis; some 24.5 million people; Mexicans suffer more than 100 hip fractures daily. ${ }^{14}$

\section{Prevalence of osteoporotic fractures}

\section{Hip fractures}

From 1990 to projections in 2050 the number of hip fractures for women and men aged 50-64 in Latin America will increase by $400 \%$. For age groups older than 65 the increase will be a staggering 700\%. ${ }^{15}$ Latin Americans will suffer an estimated 655648 hip fractures in 2050, at an estimated direct cost of $\$ 13$ billion. ${ }^{16}$

In Venezuela, in 1995 there were 9.6 hip fractures per day. In 2030 it is estimated that there will be 67 hip fractures per day. Of the people who suffer a hip fracture, $17 \%$ die in the first four months after the fracture. Clinical trials indicated that only $10 \%$ of the population older than 70 years have normal bone mineral density. ${ }^{17}$

Hip fracture incidence has been reported in Community-based and hospital discharge studies. The incidence ranges from 263 to 304 hip fractures/ 100000 persons in community studies and from 40 to 362 in hospital-based ones. As a comparison, hip fracture incidence is 331 in Rochester US. ${ }^{18-31}$

Annual rates of hip fracture in the two main public health care systems of Mexico, published in 2005 were 169 in women and 98 in men per 10000 person-year. This is the same to say that 1 out of every 12 women 50 year-old in Mexico will have a hip fracture. These rates of hip fracture are similar to the southern countries in Europe. The life-time probability of having a hip fracture at 50 years of age was 8.5 for women and 3.8 for men, this is similar to what has been found in Hong Kong and slightly lower than the observed in Spain, Portugal and France. These data support the evidence that with the increase in the fracture incidence in the next 50 years, the magnitude of the osteopororotic fracture health problem required extensive evaluation from the health care systems not only in Mexico but in the whole Latin America. ${ }^{32}$

Recently in Rosario Argentina hip fractures were reported to be, in subjects over 50 years, 405 for women and 137 for men. In population older than 65 years the incidence was 646 and 345 respectively. These values are similar to US values reported in people older than 65 years. ${ }^{33,34}$ Mean age was 79.5 year-old. This incidence of hip fracture is slightly higher than the one reported 10 years ago in another city of Argentina, Mar de Plata. ${ }^{35}$

Very recent data accepted for presentation at the next WCO, Bangkok, 2008 from Venezuela show that the incidence of hip fracture for women over 50 years was 98 and for men 37 per 100000 . The life-time probability of having a hip fracture at 50 years of age was 5.5\% for women and 1.5 for men, and for any osteoporotic fracture was $13.6 \%$ for women and $3.5 \%$ for men. 10 year probability of any osteoporotic fracture goes from $1.6 \%$ at ages 50-59 to 9.5 at age $80+$ for women and from $0.2 \%$ to $3.1 \mathrm{in} \mathrm{men.} \mathrm{At} \mathrm{age} 80$ hip fracture incidences in Venezuela are similar to many European countries like Spain, France, Greece, Hungary Italy or Portugal. ${ }^{36}$

Mortality rates are similar than the rest of the world going from 1.02 to $10 \%$ during hospital stay and 23 to $30 \%$ during the first year after fracture. This mortality rate was higher in men than women. . $^{14,20,25,31,37,38}$ In a private hospital in Mexico mortality rate was 9.8 for patients who underwent surgical procedures and 33.3\% for those who received conservative treatments. ${ }^{39}$ This 
contrasts with Venezuelan data coming from a Public University Hospital where mortality rates for patients who did not receive surgery was as high as $92 \%{ }^{40}$

\section{Vertebral fractures}

Less information is available in this area, however, data from the LAVOS, Latin American Vertebral Osteoporosis Study have been published recently showing that the prevalence of vertebral fractures in women 50 years and older is $19.35 \%$, it ranged from $8.3 \%$ in those $50-60 \mathrm{y}$-o to $37 \%$ in those 80 years and older. ${ }^{41}$ By countries, fracture incidence was 14.8 in Brazil, 12.1 in Puerto Rico and 19.5 in Mexico and increases with age. Mexico has the same prevalence as the US in subjects over 70 years, according to the SOF Study. ${ }^{42}$ In Mexican men the prevalence of vertebral fracture is half of what is found in women, 9.7 vs. 19.5, with the highest rate in older subjects over 80 years: 21.4. This supports the evidence of the impact of osteoporotic fractures in men in LA as equal as it is in the rest of the world. ${ }^{43}$

\section{Cost}

There is a wide variation in cost across the region and the information is very scarce. From the few reports available and a recent questionnaire-based study addressed to rheumatologists and experts in osteoporosis in LA, and considering the cost in USD, an acute episode of hip fracture ranges from 5500 to 8500 USD with a mean GNI of 2776 USD for the whole region. Indirect cost like diagnosis, medication, rehabilitation, medical follow-up has not been estimated so far. ${ }^{44}$ In the year 2002 reported cost for wrist fractures was 2063 USD and 2751 USD for vertebral fractures. ${ }^{45}$ In the same period 2001-2002 the estimate of total investment for the Mexican Institute of Social Security was more than 36 million dollars. ${ }^{46}$

\section{References}

I. United Nations. World Population 1995-2050 (the 1998 revision) Europe,America, and Australasia (excluding Melanesia). Population Division. Department of Economic and Social Affairs. New York, 1998. 2. Centro Latinoamericano y Caribeño de Demografía. CELADE (2000) Boletín Demográfico No, 66 América Latina: Población por Años Calendario y Edades Simples 1995-2005. Julio 2000. Cepal-Eclac. Santiago, Chile

3.World Development Indicators 200I. Size of the Economy. The World Bank Group,Washington (Available from: www.worldbank.org). (Accessed on: Sept 10, 2007).

4.World Health Organization. The World Health Report 2000. Geneva: WHO, 2000.
5. Delezé M. Cons-Molina F,Villa AR et al. (2000) Geographic differences in bone mineral density of Mexican women. Osteoporos Int 2000; I I:562-569. 6. Santos Hernández C, Hernández Martínez A, González de la Nuez J, Ugarte Suárez JC, Fernández Madero I. Estudio de Masa Ósea en la Población Cubana. Presented at the first Mexican Congress on Osteoporosis. January 12, 200I.Acapulco, México.

7. Lewin S, Gouvela CH de A, Marone,Wehba S, Malvestiti LF, Bianco AC. Densidad Mineral Osea Vertebral e Femoral de 724 Mulheres Brancas Brasileiras: Influencia da ICADE e do Peso Corporal. Rev Ass Med Brasil 1996:47:2-6.

8. Favus MJ. Bone Density referent data. In: Favus MJ (ed) Primer on the metabolic bone diseases and disorders of mineral metabolism. $2^{\text {nd }}$ ed. New York; Raven Press: 1993;426-430.

9. Szejnfeld L,Atra E, Baracat EC,Aldrighi JM, Civitelli R. Bone density in white Brazilian women: rapid loss at the time around the menopause. Calcif Tissue Int 1995;56:186-191.

10. Hui SL, Gao S, Zhou XH, Johnston CC, Lu Y, Glüer CC, et al. Universal standardization of bone density measurements: a method with optimal properties for calibration among several instruments.J Bone Miner Res 1997; |2:1463-1470.

II. International Committee for Standards in Bone Measurement. Standardization of proximal femur bone mineral density (BMD) measurements by DXA. Bone 1997;21:369-370.

12. Pastore K. Futuro frágil. Pesquisa internacional revela que médicos e pacientes não sabem tratar a osteoporose. Revista Veja. Ed 1658, 19/07/2000. (Available on: http://veja.abril.com.br/l90700/P_104.html). (Accessed on: July 27, 2007).

13. Arriagada M,Arinoviche R. Densidad Mineral Osea en Chile. Galenus 1997;9(34):33-36.

14. Gómez García F. Morbimortalidad de Fracturas de Cadera en el Hospital de Traumatología Magdalena de las Salinas. IMSS. Rev Mex Ortop Traum 1998;2:48-52. (Available from: http://www.imbiomed.com. $\mathrm{mx} / \mathrm{I} / \mathrm{l} /$ articulos.php? method=showlndex\&id_revista=32). (Accessed on: August 10, 2008).

15. Cooper C, Campion G, Melton LJ. Hip fractures in the elderly: a world-wide projection. Osteoporos Int 1992;2:285.

16. Johnell O.The socioeconomic burden of fractures: today and in the 2 Ist century. Am J Med 1997;103:20S.

17. Riera-Espinoza G. Realidad de la Osteoporosis en Venezuela. Informe Médico 2003;3(6):345-356.

18. Gallagher JC, Melton LJ, Riggs BL, Bergstrath E. Epidemiology of fractures of the proximal femur in Rochester, Minnesota. Clin Orthop Rel Res 1980;150:163-17|.

19. Bargur A, Mautalen C, Rubin Z. Epidemiology of hip fractures in an urban population of Central Argentina. Osteoporos Int 1994;4:332-335. 20. Soma LF, Rosso GZ, Trobo RI, Barreira JC, Messina OD. Epidemiología de la Fractura de Fémur Próxima en Luján. Osteology 1999;2:46-54.

21. Carmona F. Osteoporosis en Santa Fe de Bogotá. Instituto Nacional de Salud. Santa Fe de Bogotá, 1999.

22. Bacon WE, Maggi S, Looker A, Harris T, Nair CR, Giaconi J, et al. International comparison of hip fracture rates in 1988-89. Osteoporos Int 1996;6:69-75.

23. Mautalen C, Pumarino H. Epidemiology of osteoporosis in South America. Osteoporos Int 1997; 17:S73-S77.

24. Contreras GL, Kirschbaum KA, Pumarino CH. Epidemiología de las Fracturas en Chile. Rev Méd Chile 1991; I 19:92-98.

25. Morales Torres J, Hernández Ochoa C, Hernández Paz R, Hernández Morales $\mathrm{G}$. Fracturas de cadera en egresos de hospitales de León. Gto. Un indicador econométrico de Osteoporosis. Rev Mex Reumat 1997; 12:1 19124 (Available from: http://www.reumatologia.org.mx/). (Accessed on: August 10,2008).

26. Clark P, Lavielle PJ, Palermo L, Cummings S. Incident rates of hip fractures in mexicans over 50 years. JBMR 2003; 18 supl. 2; S304:SI 53. 
27. Capunay MP,Vincentelo R, Dorregaray J,Angulo J. Incidencia de fracturas de fémur proximal atribuible a osteoporosis en una población de Lima.J Clin Rheumatol 2002;8:S49 (abstract). (Available from: http://www. jclinrheum.com/pt/re/jcr/home.htm;). (Accessed on:August 10, 2008). 28. Schwartz AV, Kelsey JL, Maggi S, Tuttleman M, Ho SC, Jónsson PV, et al. International variation in the incidence of hip fractures: cross national project on osteoporosis for the World Health Organization Program for Research on Aging. Osteoporos Int 1999;9:242-253.

29. Komatsu RS, Jennings-Simoes MF, Ramos LR, Szejnfeld VL. Incidence of fractures of the proximal femur in Marilia, Sao Paulo, Brazil, 1994 and 1995. Rev Bras Reumatol 1999;39:325-331. (Available from: http://www. scielo.br/scielo.php/script_sci_serial//ng_pt/pid_0482-5004/nrm_iso). (Accessed on:August 10,2008).

30. Chue de Coto E. The incidence of hip fractures in pre and postmenopausal women in Panama. Rev Med Panama 1997;22:30-38. 31. Miraval Niño de Guzmán T, Segami SI, Chávez CJ, Pastrana J, Monteza JC,Alarcón JM. Fractura de cadera a trauma mínimo en mayores de 50 años: Morbimortalidad, pronóstico funcional. Rev Per Reumatol 2000;6:68. (Available from:

http://sisbib.unmsm.edu.pe/bVrevistas/reuma/v06_n2/pres_oral_ a.htm\#6.\%20FRACTURA). (Accessed on:August 10, 2008).

32. Clark P, Lavielle P, Franco-Marina F, Ramírez E, Salmerón J, Kanis JA, et al. Incidence rates and life-time risk of hip fractures in Mexicans over 50 years of age: a population-based study. Osteoporos Int 2005; I6(I2):2025-2030. 33. Hinton RY, Lennox DW, Ebert FR, Jacobsen SJ, Smith GS. Relative rates of fracture of the hip in the United States. Geographic, sex, and age variations.J Bone Joint Surg 1995;77A:695-702.

34. Jacobsen SJ, Goldberg J, Miles TP, Brody JA, Stiers W, Rimm AA. Hip fracture incidence among the old and very old: a population-based study of 745,435 cases. Am J Public Health 1990;80:87I-873.

35. Mosquera MT, Maurel DL, Pavón S,Arregui A, Moreno C,

Vásquez $J$. Incidencia y factores de riesgo de la fractura de

fémur proximal por osteoporosis. Panam J Public Health

1998;3:2I I-2 18. (Available from: http://journal.paho.org/

?s=maternal*reproductive*Breastfeeding\&searchbutton=Go). (Accessed on:August 10, 2008).36. Hannan EL, Magaziner J,Wang JJ, Eastwood EA, Silberzweig SB, Gilbert M, et al. Mortality and locomotion 6 months after hospitalization for hip fractures: risk factors and risk-adjusted hospital outcomes. JAMA 200I;285:2736-2742.

37. Riera-Espinoza, G. López D, Kanis JA. Life-time risk of hip fracture and incidence rates in Carabobo,Venezuela.WCO of IOF, Bangkok, 2008. (www.iofbonehealth.org). (Accepted for presentation).
38. Bargur A, Mautalen C, Rubin Z. Epidemiology of hip fractures in an urban population of Central Argentina. Osteoporos Int 1994;4:332-335. 39. Castañeda P, Cassis N. Mortalidad posterior a fracturas de cadera tratadas en el Centro Medico ABC entre 1996 y 200I. An Med Asoc Med Hosp ABC 2003;48:33-37. (Available from:

http://www.medigraphic.com/espanol/e-htms/e-abc/e-bc2003/e-bc03-I/ em-bc03 If.htm). (Accessed on:August 10, 2008).

40. Nieto-Andueza E, Useche R, Natale A. Mortalidad extra hospitalaria luego de una fractura de cadera. REEMO 200 I;I0(3):8I-85. (Available from: http://db.doyma.es/cgi-bin/wdbcgi.exe/doyma/mrevista_info. sobre? pident_revista=70). (Accessed on:August 10,2008).

4I. Clark P, Deleze M, Cons-Molina F, Salmeron J, Palermo L, Cummings SR. The LAVOS Study Group. Prevalence of vertebral fractures in Mexico:A population-based study. 2005,ASBMR 27th Annual Meeting in Nashville, Tennessee, USA.Abstract SU270. (Available from: http://www.abstractsonline.com/viewer/viewAbstractPrintFriendly. asp? CKey $=\{$ FFC52500-9449-46F8-B804-7ADE89D7ADF3 $\} \& S K e y=\{F 58$ 64960-7A I5-43C6-BE70-D3DB8D6AIID9 $\& M K e y=\{23$ IF6D2C-6C944AIC-8C62-I0CC89E46254 $\&$ AKey $=\{D 0 C 0 I D 4 F-E 23 B-45 E 2-A C D 4-$ 0AF8AC866B8B\}). (Accessed on:August 10, 2008).

42. Clark P, Ragi S, Haddock L, Suarez E, Pérez C, Cons Molina F, et al. Prevalence of Vertebral Fractures in Brazil, Puerto Rico and Mexico. Preliminary Report of the Latin American Vertebral Osteoporosis Study (LAVOS). 2004,ASBMR 26th Annual Meeting in Seattle, Washington, USA. Abstract SA340. (Available from: http://www.abstractsonline.com/viewer/ viewAbstractPrintFriendly.asp? CKey $=\{395 F 2$ AIC-F8CE-4I8B-A343-4I 43 2FI044E5 $\} \& S K e y=\{A D 8 D 3444-6 D B C-4652-B 65 E-F A E C 2 A A E 5 B I E\} \& M K e$ $y=\{969|5 C 07-D| 10-439 D-B F 0 C-C 23 C D 3392 D 2 D\} \& A K e y=\{D 0 C 0 \mid D 4 F-$ E23B-45E2-ACD4-0AF8AC866B8B\}). (Accessed on:August 10, 2008). 43. Clark P, Cons Molina F, Ragi S, Deleze M, Haddock L, Zanchetta JR, et al. The prevalence of vertebral fractures in Latin American women: the Latin American Vertebral Osteoporosis Study "LAVOS". Osteoporosis International 2006 I7 Supl 2; OCl.

44. Morales-Torres J, Gutiérrez-Ureña S. The burden of osteoporosis in Latin America. Osteoporos Int 2004;15:625-632.

45. Cruz I, Cisneros F, Salazar R, Tejeida A. Costos institucionales y dificultades en la atención de los pacientes con fracturas por osteoporosis. Act Ortopédica Mexicana 2002;16(6):292-295.

46. Velasco-Murillo V. Fracturas en mujeres posmenopáusicas en el IMSS: frecuencia y costos de su atención hospitalaria. Gac Med Mex 2003; 135(5):453-458. 